American Journal of Microbiology 1 (2): 23-29, 2010

ISSN 1948-982x

(c) 2010 Science Publications

\title{
Microbial Consortia from Taptapani Hot Water Springs for Mining Effluent Treatment
}

\author{
${ }^{1}$ Poonam Nasipuri, ${ }^{2}$ Gauri G. Pandit, \\ ${ }^{3}$ Ashoke Ranjan Thakur and ${ }^{1}$ Shaon Ray Chaudhuri \\ ${ }^{1}$ Department of Biotechnology, West Bengal University of Technology, \\ BF-142, Sector-1, Salt Lake, Calcutta-700064, India \\ ${ }^{2}$ Environmental Assessment Division, Bhabha Atomic Research Center, \\ Trombay, Mumbai-400085, India \\ ${ }^{3}$ Vice Chancellors Office, West Bengal State University Barasat, \\ Berunanpukuria, P.O. Malikapur, North 24 Parganas-700126, India
}

\begin{abstract}
Problem statement: Soluble sulfate load in effluent is a crucial problem from mining industries. The study involved isolation of efficient Sulfate Reducing Bacterial (SRB) consortium from hot water spring for bioremediatrion of sulfate contaminated waste water. Approach: The enriched bacterial consortium was isolated in medium DSMZ 16695. The sulfate reduction efficiency was measured by turbidometric method. The $K_{m}$ and $R_{\max }$ value of the consortium was determined. It was immobilized in 10L bioreactor and the sulfate reduction was measured in presence of media and mine effluent. Results: The consortium was found to reduce $2000 \mathrm{ppm}$ of sulfate in $36 \mathrm{~h}$ under optimum condition. The $\mathrm{K}_{\mathrm{m}}$ of $1.1530 \mathrm{ppm}$ and $\mathrm{R}_{\max }$ value of $0.030 \mathrm{~h}^{-1}$ was obtained under optimum conditions of pH-7.5 at $40^{\circ} \mathrm{C}$ with $2 \%$ inoculum. Consortium immobilized under ambient condition in a $10 \mathrm{~L}$ packed bed reactor yielded about $21-41 \%$ reduction of soluble sulfate in synthetic medium prepared using effluent water and tap water respectively. Conclusion: This study reports for the first time the use of efficient SRB consortia from hot water spring for bioremediation of mine effluent.
\end{abstract}

Key words: Sulfate reducing bacteria, sulfate remediation, packed bed bioreactor, taptapani hot water spring, microbial consortium

\section{INTRODUCTION}

Sulfate concentration is found to rise in natural water due to various anthropogenic activities. It is released into the environment due to various industrial activities (Nasipuri et al., 2010; Liamleam and Annachhatre, 2007) like mining procedure and atmospheric deposition in the form of acid rain (Bull et al., 2001). Increase in sulfate concentration in ground water causes various adverse effects like laxative effect (Zuhair et al., 2008) skin in problem, dehydration, as well as unpleasant taste of water. Lowering of ground water table due to agricultural reasons helps the oxygen to invade the anoxic layer oxidizing the iron sulfides to Fe (III) hydroxides and sulfate (Zak et al., 2006).The sulfate leaches to the ground water leading to increase in sulfate concentration (Zak et al., 2006). It had also been reported that sulfate pollution could lead to eutrophication of surface water (Zak et al., 2006).
Increased sulfate concentration causes phosphate mobilization aggravating phosphate eutrophication that can inhibit the growth of different plant species (Geurts et al., 2008). Chemical means of decontaminating the soluble sulfate like reverse osmosis, distillation and ion exchange have various drawbacks including the high operational cost (Preez and Maree, 1994) Alternative way of solving the problem is by using Sulfate Reducing Bacteria (SRB) for bioremediation of both sulfate and metals.

SRB use sulfate as their terminal electron acceptor reducing it to hydrogen sulfide as the end product through dissimilatory sulfate reduction pathway (Rabus et al., 2006). The hydrogen sulfide thus produced has high affinity for divalent metals reducing them to insoluble metal sulfide which makes them technologically important not only for soluble sulfate removal but also for metal removal (Nasipuri et al., 2010, Hammack and Edenborn, 1992; Colleran et al.,

Corresponding Author: Shaon Ray Chaudhuri, Department of Biotechnology, West Bengal University of Technology, BF-142, Sector-1, Salt Lake, Calcutta-700064, India Tel: +913323210731 ext 108; +919831034236

Fax: +913323341030 
1995; Hoa et al., 2007; Biswas et al., 2008). Thus the reduction of sulfate by SRB is the most important step for both metal and sulfate removal from waste water (Baskaran and Nemati, 2006; Alvarez et al., 2007; Hsu et al., 2010). Organic barriers like Zero Valent Iron (ZVI) plays an important role here by favoring the growth of SRB and that in turn produces sulfide which helps in metal removal (Fiore and Zanetti, 2009). SRB are found to be distributed widely in nature due to their various interactions like geochemical transformation, turnover of organic matter, cycling of the nutrient, bioremediation, biocorrosion (Barton and Tomei, 1995; Fauque, 1995). Although they are found in varied geographical habitat they have similar characteristics (George et al., 2008).

Hot water springs all over the world are reported to harbor thermophilic bacteria (Al-Quadan et al., 2009) and SRB are frequently found due to the high content of sulfate (Fathi and Al-Kahtani, 2009; Ghanem and Ghannam, 2010; Dillon et al., 2007). However studies on presence of SRB from hot water springs of India are rare (George et al., 2008). The present study reports the sulfate reduction efficiency of the SRB consortium (G16695), isolated from hot water springs of Taptapani, Orissa in a packed bed bioreactor under ambient condition using both synthetic media and mining effluent water.

\section{MATERIALS AND METHODS}

Sampling site and sampling procedure: Water and soil samples were collected from Taptapani $\left(84^{\circ} 40^{\prime} \mathrm{E}\right.$ and $19^{\circ} 50^{\prime} \mathrm{N}$ ) hot water spring (Orissa) in India and carried in sterile plastic containers to the laboratory at ambient temperature for further analysis.

Enrichment, cultivation and morphological characterization: Medium DSMZ-16695 as per the specifications of German Collection of Microorganisms and Cell Cultures (Deutsche Sammlung von Mikroorganismen und Zellkulturen GmbH) (http://www.dsmz.de/microorganisms) was used for enrichment and cultivation of the consortia from hot water spring. $2 \%$ inoculum of water was directly added to the anaerobic media. For generation of anaerobicity sealed serum vials were taken and reducing agents like sodium dithionite and sodium bi-carbonate were added prior to purging with nitrogen. Soil sample was diluted in sterile water and the particulate matter was allowed to settle down. The supernatant was then used as inoculum at a similar concentration (2\%). The vials were incubated at $40^{\circ} \mathrm{C}$ for $24 \mathrm{~h}$ and the growth and sulfate reduction was measured at $12 \mathrm{~h}$ interval until complete reduction was observed.
Sulfate measurement by turbidometric method: The turbidometric method reported by Nasipuri et al. (2010) was followed for measurement of sulfate concentration.

Determination of sulfate reduction kinetics: Monod (1949) kinetics was calculated to understand the substrate dependent microbial activity demonstrated by the consortium according to the formula:

$\mathrm{t} /(\operatorname{lnCc} / \mathrm{Cco})=(\mu+1) / \mathrm{k}+\mu / \mathrm{k}\left(\operatorname{lnCa}_{0} / \mathrm{Ca}\right) /\left(\operatorname{lnCc} / \mathrm{Cc}_{0}\right)$

Where:

$\mathrm{t}=$ Time

$\mathrm{Ca}=$ Substrate concentration at time ' $\mathrm{t}$ '

$\mathrm{Ca}_{0}=$ Initial substrate concentration

$\mathrm{Cc}=$ Cell $\mathrm{OD}_{660}$ at time ' $\mathrm{t}$ '

$\mathrm{Cc}_{0}=$ Initial cell OD 660

$\mathrm{k}=$ Maximum rate of sulfate utilization.

$\mu=\mathrm{Km} /\left(\mathrm{Ca}_{0}+\mathrm{Y}_{\mathrm{A} / \mathrm{C}} \mathrm{Cc}_{0}\right)$; where

$\mathrm{Y}_{\mathrm{A} / \mathrm{C}}=$ The slope between $\mathrm{Ca}$ and $\mathrm{Cc}$

$\mathrm{Km}=$ Half saturation constant

Finally the rate of the reaction can be calculated as:

$\mathrm{R}=\left(\mathrm{R}_{\max } * \mathrm{~S}\right) /\left(\mathrm{K}_{\mathrm{m}}+\mathrm{S}\right)$

Where:

$\mathrm{R} \quad=$ Rate of sulfate utilization

$\mathrm{R}_{\max }=$ Maximum rate of sulfate utilization; equivalent to ' $k$ ' of Eq. 1

$\mathrm{K}_{\mathrm{m}}=$ Half saturation constant

$\mathrm{S}$ = Substrate concentration; Equivalent to $\mathrm{Ca}$ of Eq. 1

The reason for taking Eq. 1 is due to the large time gap (12 h) between two sampling.

Here substrate is replaced by the sulfate concentration. The graph was plotted from the above equation with $(\operatorname{lnCao} / \mathrm{Ca}) /(\operatorname{lnC} / \mathrm{Cco})$ on the $\mathrm{X}$ axis against $t /(\operatorname{lnCc} / \mathrm{Cco})$ on the $\mathrm{Y}$ axis. The slope and intercept were calculated from the graph and subsequently $\mathrm{R}_{\max }$ and $\mathrm{K}_{\mathrm{m}}$ was determined.

Immobilization of Consortium in $10 \mathrm{~L}$ packed bed bioreactor: In order to be used continuously as a bioremedial package, immobilization was a better choice than suspension culture due to two reasons. Firstly it reduces the cost as well as effort of addition of fresh inoculum with each cycle making the operation less cumbersome. Secondly the biofilm developed would be more robust as compared to suspended cells against inhibitors that might be present in the environmental effluent. 
Am. J. Microbiology 1 (2): 23-29, 2010

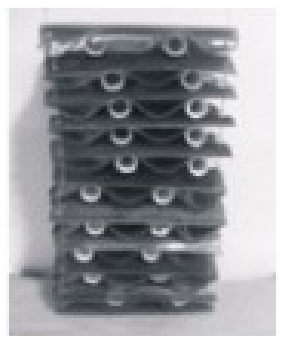

(a)

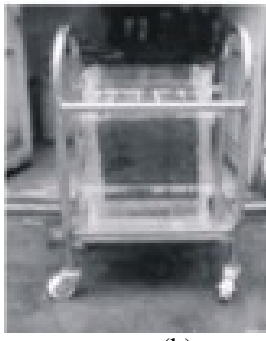

(b)
Fig. 1: Immobilization matrix for packed bed reactor. (a) Photograph representing the arrangement of the packed plastic sheets used for immobilization; (b) Photograph of the bioreactor with packed bed matrix inside

Thus immobilization was tried out on packed corrugated sheets (Fig. 1a) placed inside $10 \mathrm{~L}$ bioreactor (Fig. 1b). For charging of the bioreactor, 10 $\mathrm{L}$ medium was inoculated with $10 \%$ culture and the corrugated sheets were kept submerged for $24 \mathrm{~h}$. The culture was decanted after $24 \mathrm{~h}$ and the sheets were left for another $6 \mathrm{~h}$ to facilitate adhesion of the cells onto the surface. Fresh medium was added and the percentage of sulfate reduction was studied at $24 \mathrm{~h}$ interval. The anaerobicity was not maintained externally but left to the continuous generation of $\mathrm{H}_{2} \mathrm{~S}$ by SRB. The medium was decanted every $24 \mathrm{~h}$ and replaced by fresh medium to facilitate the microbial growth and reduction. The entire operation was conducted under ambient temperature in absence of nitrogen purging. Similar procedure was repeated with mining effluent where medium was prepared eliminating sulfate salt and replacing distilled water by mining effluent water.

\section{RESULTS}

Characterization of the consortia: The consortium was found to reduce $2000 \mathrm{ppm}$ of soluble sulfate from both synthetic media and waste within $36 \mathrm{~h}$. The $\mathrm{K}_{\mathrm{m}}$ of $1.1530 \mathrm{ppm}$ and $\mathrm{R}_{\max }$ value of $0.030 \mathrm{~h}^{-1}$ was found (Fig. 2). The community morphology of the consortia showed the predominance of bacilli followed by vibrio and cocci. Molecular analysis of 25 clones (GQ503829GQ503853) revealed maximum similarity with thermophilic isolates like Clostridium thermopalmarium and Clostridium thermobutyricum. This is expected since the consortium was enriched from hot water spring (Al-Quadan et al., 2009). The OTU saturation curve indicated completeness of the study while the Shannon diversity index of 0.950 and equitability index of 0.590 represented less diversity as well as non even distribution of members of the consortium (Al-Quadan et al., 2009). This is also expected as selective media was used for the purpose.

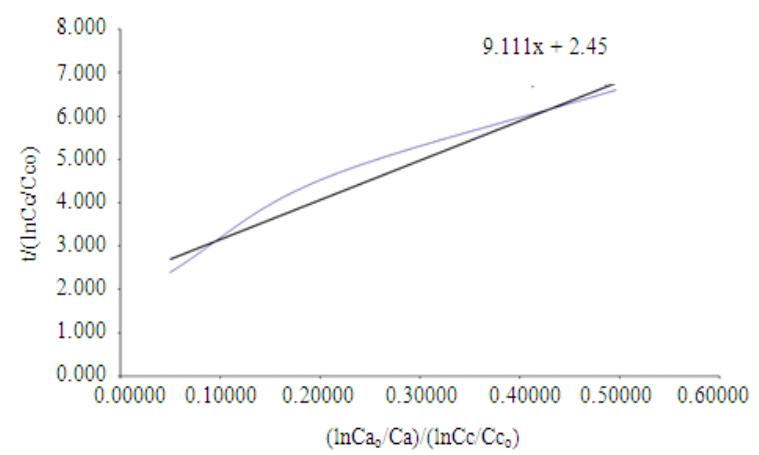

Fig. 2: Graph representing the plot for determination of $K_{m}$ and $R_{\max }$ for the consortium where the intercept is $(\mu+1) / k$ and slope is $\mu / k$

Immobilization of the consortium: Immobilization of living microorganisms and enzymes has been described by several investigators (Nasratun et al., 2009; Salemi, 2010; Yusilawati et al., 2010; Fedorak et al., 1985; Friday and Portier, 1991; Durham et al., 1994b) as being useful not only for the production of chemicals for industrial use but also for degradation of chemical pollutants by bacteria where they colonize on the immobilized surface and form biofilms. They are also found to be advantageous over suspended-cell growth (Friday and Portier, 1991; Durham et al., 1994a; 1994b; Shimp and Pfaender, 1982; Ehrhardt and Rehm, 1985) for bioremedial purpose. Bacteria immobilized in gels like alginate are surrounded by a gel network, which strongly limits their movement but their metabolic activity is not hampered. However due to accumulation of gas alginate beads tend to rupture after some time. Immobilization inside packed bed bioreactor had been reported with rice straw (Tao et al., 2010) as well as waste paper. Bioreactors has been well reported for removal of pollutants (Arbabi et al., 2009). Here the immobilization was tried out on corrugated sheets. Since the aim of the work was construction of simplest form of bioreactor no mechanical agitation was given to inhibit oxygenation (Mohamed et al., 2009), to mimic the native application as would prevail in the treatment plant, no nitrogen was purged and it was allowed to grow under ambient temperature $\left(\sim 30^{\circ} \mathrm{C}\right)$. As evident from Fig. 3a and b there was $41 \%$ reduction in medium while $21 \%$ in modified media made from effluent water under ambient condition. 


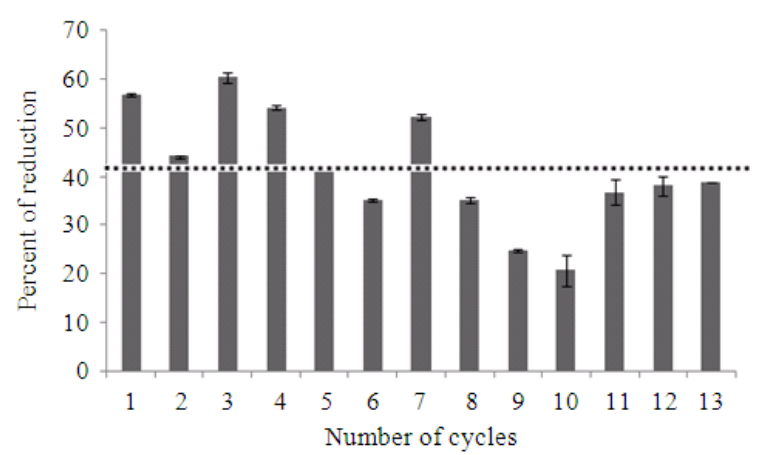

(a)

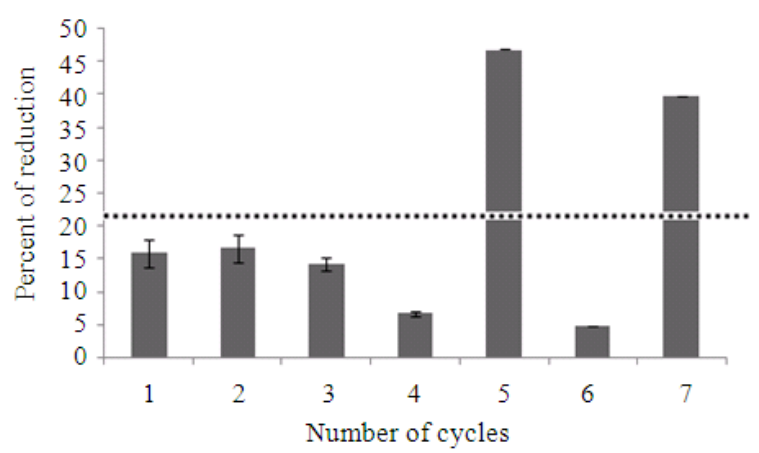

(b)

Fig. 3: Sulfate reduction in packed bed reactor. (a) Bar diagram representing the percentage of sulfate reduction after every $24 \mathrm{~h}$ in $10 \mathrm{~L}$ packed bed reactor in presence of medium DSMZ-16695 with recharging each $24 \mathrm{~h}$. X axis represents the number of cycles of recharging with fresh medium while the straight dotted line represents the average sulfate reduction per day; (b) Bar diagram representing the percentage of sulfate reduction in $10 \mathrm{~L}$ packed bed bioreactor in presence of modified medium made using waste water instead of distilled water. $\mathrm{X}$ axis represents the number of cycles (of $24 \mathrm{~h}$ each) for which the reactor was charged with modified media. The straight dotted line represents the average sulfate reduction per day

\section{DISCUSSION}

The consortium isolated from hot water spring was found to reduce sulfate efficiently from 2000ppm in $36 \mathrm{~h}$ when grown under anaerobic condition at optimum temperature $\left(40^{\circ} \mathrm{C}\right)$ in sealed serum vials. Upon immobilization it was found to work better in synthetic medium as compared to waste water which may be due to the presence of inhibitors in the mine effluent. It was found to reduce 41 and $21 \%$ of sulfate on an average per day from media and waste water respectively as compared to $66 \%$ (in 24h) reduction under optimum growth condition (anaerobic, $\mathrm{pH} 7.5$, temperature $40^{\circ} \mathrm{C}$ ) (Al-Quadan et al., 2009). The $\mathrm{K}_{\mathrm{m}}$ of $1.1530 \mathrm{ppm}$ and $\mathrm{R}_{\max }$ value of $0.030 \mathrm{~h}^{-1}$ was within the range reported for different SRB (Ingvorsen and Jørgensen, 1984; Ingvorsen et al., 1984; Sonne-Hansen et al., 1999; Roychoudhury and Dean, 2006). The $K_{m}$ value was much lower as compared to other hot water spring isolates reported earlier (Roychoudhury, 2004) while found to be comparable to fresh water SRB (Roychoudhury and Dean, 2006; Ingvorsen et al., 1981). However since the value of these variables was dependent on the initial sulfate concentration (Zuhair et al., 2008; Moosa et al., 2005) the comparison may not be quite valid. This is the first report of isolation of efficient SRB consortium from the hot water spring of Taptapani at Gunupur in India, for treatment of mine effluent.

\section{CONCLUSION}

Bioremediation by bacteria has been well reported since it's both cost effective and efficient in terms of acclimation time (Nasipuri et al., 2010; Adeyemi, 2009; Mukherjee et al., 2010; Olajide and Ogbeifun, 2010). The results clearly depicts that bioremediation of soluble sulfate can be done with this novel consortium. However since different metals may have inhibitory effect on the microbial growth (Deeb and Altalhi, 2009) the composition of the waste water may determine the sulfate reduction efficiency of the consortium.

\section{ACKNOWLEDGMENT}

Authors acknowledge the members of Bhabha Atomic Research Centre who were associated directly or indirectly with the project; West Bengal University of Technology and Department of Biotechnology, Govt. of India for the computational facility; Mr. R.G. Mukhopadhyay, Mr. V.N. Jha and his group of Uranium Corporation of India Limited (UCIL), Jharkhand for assistance during sample collection; Prof. Pinaki Bhattacharyya of Jadavpur University for help during the mathematical calculations; Ms. Ananya Banerjee, Ms. Arpita Pani, Mr. Bodhajnya Kumar Mishra, Ms. Deepika Panigrahi, Ms Mukul Bastia and Mr. Rakesh Prakash Padhy of Gandhi Institute of Technology for their help during sample collection and the bioreactor based experiment.

\section{REFERENCES}

Adeyemi, A.O., 2009. Bioaccumulation of arsenic by fungi. Am. J. Environ. Sci., 5: 364-370. DOI: 10.3844/ajessp.2009.364.370 
Al-Quadan, F., H. Akel and R. Natshi, 2009. Characteristics of a novel highly thermostable and extremely thermophilic alkalitolerant amylase from hyperthermophilic bacillus strain HUTBS71. OnLine J. Biol. Sci., 9: 67-74. DOI: 10.3844/ojbsci.2009.67.74

Alvarez, M.T., C. Crespo and B. Mattiasson, 2007. Precipitation of $\mathrm{Zn}$ (II), $\mathrm{Cu}$ (II) and $\mathrm{Pb}$ (II) at bench-scale using biogenic hydrogen sulfide from the utilization of volatile fatty acids. Chemosphere, 66: 1677-1683. DOI: 10.1016/j.chemosphere.2006.07.065

Arbabi, M., M. Sadeghi and Ch. Anyakora, 2009. Phenanthrene contaminated soil biotreatment using slurry phase bioreactor. Am. J. Environ. Sci., 5: 223-229. DOI: 10.3844/ajessp.2009.223.229

Barton, L.L. and F.A. Tomei, 1995. Characteristics and Activities of Sulphate-Reducing Bacteria. In: Sulphate-Reducing Bacteria, Barton, L.L. (Ed.). Plenum Press, New York, pp: 1-32. ISBN: 0306448572

Baskaran, V. and M. Nemati, 2006. Anaerobic reduction of sulfate in immobilized cell bioreactors, using a microbial culture originated from an oil reservoir. Biochem. Eng. J., 31: 148159. DOI: 10.1016/j.bej.2006.07.007

Biswas, K.C., N.A. Woodards, H. Xu and L.L. Barton, 2008. Reduction of molybdate by sulfate-reducing bacteria. Biometals, 22: 131-139. DOI: 10.1007/s10534-008-9198-8

Bull, K.R., B. Achermann, V. Bashkin, R. Chrast and G. Fenech et al., 2001. Coordinated effects monitoring and modelling for developing and supporting international air pollution control agreements. Water, Air, Soil Pollut., 130: 119-130 DOI: 10.1023/A:1012255604267

Colleran, E.S., S. Finnegan and P. Lens, 1995. Anaerobic treatment of sulphate-containing waste streams. Antonie van Leeuwenhoek., 67: 29-46. DOI: $10.1007 / B F 00872194$

Deeb, B.E. and A.D. Altalhi, 2009. Degradative plasmid and heavy metal resistance plasmid naturally coexist in phenol and cyanide assimilating bacteria. Am. J. Biochem. Biotechnol., 5: 84-93. DOI: 10.3844/ajbbsp.2009.84.93

Dillon, J.G., S. Fishbain, S.R. Miller, B.M. Bebout and K.S. Habicht et al., 2007. High rates of sulfate reduction in a low-sulfate hot spring microbial mat are driven by a low level of diversity of sulfaterespiring microorganisms. Applied Environ. Microbiol., $\quad 73$ : 5218-5226. DOI: 10.1128/AEM.00357-07
Durham, D.R., L.C. Marshall, J.G. Miller and A.B. Chmurny, 1994a. New composition biocarriers engineered to contain adsorptive and ion-exchange properties improve immobilized-cell bioreactor process dependability. Applied Environ. Microbiol., $\quad 60$ : 4178-4181. http://www.ncbi.nlm.nih.gov/pmc/articles/PMC201 956/pdf/aem00028-0288.pdf

Durham, D.R., L.C. Marshall, J.G. Miller and A. B. Chmurny, 1994b. Characterization of inorganic biocarriers that maoderate system upsets during fixed-film biotreatment process. Applied Environ. Microbiol., 60 : 3329-3335. http://www.ncbi.nlm.nih.gov/pmc/articles/PMC201 806/pdf/aem00026-0303.pdf

Ehrhardt, H.M. and H.J. Rehm, 1985. Phenol degradation by microorganisms absorbed on activated carbon. Applied Microbiol. Biotechnol., 21: 32-36. DOI: $10.1007 / B F 00252358$

Fathi, A.A. and M.A. Al-Kahtani, 2009. Water quality and planktonic communities in al-Khadoud spring, al-Hassa, Saudi Arabia. Am. J. Environ. Sci., 5: 434-443. DOI: 10.3844/ajessp.2009.434.443

Fauque, G.D., 1995. Ecology of Sulphate-Reducing Bacteria. In: Sulphate-Reducing Bacteria, Barton, L.L. (Ed.). Plenum Press, New York, pp: 217-241. ISBN: 0306448572

Fedorak, P.M., E. Knettig and S.E. Hrudey, 1985. The effects of activated carbon on methonogenic degradation of phenolics in $\mathrm{H}$-coal waste water. Environ. Technol. Lett., 6: 181-188. DOI: 10.1080/09593338509384335

Fiore, S. and M.C. Zanetti, 2009. Preliminary tests concerning zero-valent iron efficiency in inorganic pollutants remediation. Am. J. Environ. Sci., 5: 556-561. DOI: 10.3844/ajessp.2009.556.561

Friday, D.L. and R.J. Portier, 1991. Development of an immobilized microbe bioreactor for VOC applications. Environ. Prog., 10: 30-39. DOI: 10.1002/ep.670100113

George, J., C.S. Purushothaman and Y.S. Shouche, 2008. Isolation and characterization of sulphatereducing bacteria Desulfovibrio vulgaris from Vajreshwari thermal springs in Maharashtra, India. World J. Microbiol. Biotechnol., 24: 681-685. DOI: $10.1007 / \mathrm{s} 11274-007-9524-2$

Geurts, J.J.M., A.J.P. Smolders, J.T.A. Verhoeven, J.G.M. Roelofs and L.P.M. Lamers, 2008. Sediment Fe: $\mathrm{PO}_{4}$ ratio as a diagnostic and prognostic tool for the restoration of macrophyte biodiversity in fens waters. Freshwater Biol., 53: 2101-2116. DOI: $\quad 10.1111 / j .1365-$ 2427.2008.02038.x 
Ghanem, M. and S. Ghannam, 2010. Spring water hydrochemistry along the North-South profile in the Jordan valley. Asian J. Earth Sci., 3: 122-129. http://md1.csa.com/partners/viewrecord.php?reque ster=gs\&collection=ENV\&recid=13235431

Hammack, R.W. and H.M. Edenborn, 1992. The removal of nickel from mine waters using bacterial sulfate reduction. Applied Microbiol. Biotechnol., 37: 674-678. DOI: 10.1007/BF00240748

Hoa, T.T.H., W. Liamleam and A.P. Annachhatre, 2007. Lead removal through biological sulfate reduction process. Bioresource Technol., 98: 25382548. DOI: 0.1016/j.biortech.2006.09.060

Hsu, H.F., Y.S. Jhuo, M. Kumar, Y.S. Ma and J.G. Lin, 2010. Simultaneous sulfate reduction and copper removal by a PVA-immobilizedsulfate reducing bacterial culture. Bioresource Technol., 101: 43544361. DOI: 10.1016/j.biortech.2010.01.094

Ingvorsen, K. and B.B. Jørgensen, 1984. Kinetics of sulfate uptake by freshwater and marine species of Desulfovibrio. Arch. Microbiol., 139: 61-66. DOI: 10.1007/BF00692713

Ingvorsen, K., A.J.B. Zehnder and B.B. Jørgensen, 1984. Kinetics of sulfate and acetate uptake by Desulfobacter postgatei. Applied Environ. Microbiol., 47: 403-408. http://www.ncbi.nlm.nih.gov/pmc/articles/PMC239 682/pdf/aem00159-0189.pdf

Ingvorsen, K., J.G. Zeikus and T.D. Brock, 1981. Dynamics of bacterial sulfate reduction in a eutrophic lake. Applied Environ. Microbiol., 42: 1029-1036.

http://www.ncbi.nlm.nih.gov/pmc/articles/PMC244 150/pdf/aem00193-0111.pdf

Liamleam, W. and A.P. Annachhatre, 2007. Electron donors for biological sulfate reduction. Biotechnol. Adv., 25: 452-463. DOI: 10.1016/j.biotechadv.2007.05.002

Mohamed, M.S., R. Mohamad, R.N. Ramanan, M.A. Manan and A.B. Ariff, 2009. Modeling of oxygen transfer correlations for stirred tank bioreactor agitated with atypical helical ribbon impeller. Am. J. Applied Sci., 6 : 848-856. DOI: 10.3844/ajassp.2009.848.856

Monod, J., 1949. The growth of bacterial cultures. Ann. Rev. Microbiol., 3: 371-394. http://www.rpgroup.caltech.edu/courses/PBL/imag es_bootcamp0907/Monod\%201949.pdf

Moosa, S., M. Nemati and S.T.L. Harrison, 2005. A kinetic study on anaerobic reduction of sulfate, Part II: incorporation of temperature effects in the kinetic model. Chem. Eng. Sci., 60: 3517-3524. DOI: 10.1016/j.ces.2004.11.036
Mukherjee, I., P. Bhaumik, M. Mishra, A.R. Thakur and S. RayChaudhuri, 2010. Bheri-a unique example of biological complex system. OnLine J. Biol. Sci., 10: 1-10. DOI: 10.3844/ojbsci.2010.1.10

Nasipuri, P., G.G. Pandit, A.R. Thakur and S.R. Chaudhuri, 2010. Comparative study of soluble sulfate reduction by bacterial consortia from varied regions of India. Am. J. Environ. Sci., 6: 152-158. DOI: 10.3844/ajessp.2010.152.158

Nasratun, M., H.A. Said, A. Noraziah and A.N.A. Alla, 2009. Immobilization of lipase from Candida rugosa on chitosan beads for transesterification reaction. Am. J. Applied Sci., 6: 1653-1657. DOI: 10.3844/ajassp.2009.1653.1657

Olajide, P.O. and L.B. Ogbeifun, 2010. Hydrocarbon biodegrading potentials of a Proteus vulgaris strain isolated from fish samples. Am. J. Applied Sci., 7: 922-928. DOI: 10.3844/ajassp.2010.922.928

Preez, L.A.D. and J.P. Maree, 1994. Pilot-scale biological sulphate and nitrate removal utilizing producer gas as energy source. Water Sci. Technol., 30: 275-285. http://www.bvsde.paho.org/bvsair/e/repindex/repi5 4/pilot/pilot.html

Rabus, R., T.A. Hansen and F. Widdel, 2006. Dissimilatory sulfate and sulfur-reducing prokaryotes. Prokaryotes, 2: 659-768. DOI: 10.1007/0-387-30742-7-22

Roychoudhury, A. N. and W.McC. Dean, 2006. Kinetics of sulfate reduction in a coastal aquifer contaminated with petroleum hydrocarbons. Biogeochemistry, 81: 17-31. DOI: 10.1007/s10533-006-9027-5

Roychoudhury, A.N., 2004. Sulfate respiration in extreme environments: A kinetic study. Geomicrobiol J., 21: 33-43. DOI: 10.1080/01490450490253446

Salemi, Z., 2010. Tailor-made enzyme carriers: Preparation and use of adsorbents specifically designed to immobilize allosteric enzymes in activated conformation. Am. J. Biochem. Biotechnol., 6: 111-115. DOI: 10.3844/ajbbsp.2010.111.115

Shimp, R.J. and F.K. Pfaender, 1982. Effect of surface area and flow rate on marine bacterial growth in activated carbon column. Applied Environ. Microbiol., 44: 471-477. http://www.ncbi.nlm.nih.gov/pmc/articles/PMC242 034/pdf/aem00177-0225.pdf

Sonne-Hansen, J., P. Westermann and B.K. Ahring, 1999. Kinetics of sulfate and hydrogen uptake by the thermophilic sulfate-reducing bacteria Thermodesulfobacterium sp Strain JSP and Thermodesulovibria sp Strain R1Ha3. Applied Environ. Microbiol., 65: 1304-1307. http://aem.asm.org/cgi/reprint/65/3/1304 
Tao, X.-Q., J.-P. Liu, G.-N. Lu, X. Guo and H.-P. Jiang et al., 2010. Biodegradation of phenanthrene in artificial seawater by using free and immobilized strain of Sphingomonas sp.GY2B. Afr. J. Biotechnol., 9: 2654-2660. http://www.academicjournals.org/AJB/PDF/pdf201 0/3May/Tao\%20et\%20al.pdf

Yusilawati, A.N., M. Maizirwan, M.S. Hamzah, K.H. Ng and C.S. Wong, 2010. Surface modification of polystyrene beads by ultraviolet/ozone treatment and its effect on gelatin coating. Am. J. Applied Sci., 7: 724-731. DOI: 10.3844/ajassp.2010.724.73
Zak, D., A. Kleeberg and M. Hupfer, 2006. Sulphatemediated phosphorus mobilization in riverine sediments at increasing sulphate concentration, River Spree, NE Germany. Biogeochemistry, 80: 109-119. DOI: 10.1672/09-102D.1

Zuhair, S.A., M.H.E. Naas and H.A. Hassani, 2008. Sulfate inhibition effect on sulfate reducing bacteria. J Biochem. Tech., 1: 39-44. http://jbiochemtech.com/2first.pdf 